\title{
USE OF FORCE IN CYBERSPACE
}

\author{
Jozef Valuch ${ }^{1}$ \\ Comenius University in Bratislava, Slovakia \\ jozef.valuch@flaw.uniba.sk \\ \&
}

Ondrej Hamulák ${ }^{2}$

Palacký University Olomouc, Czech Republic ondrej.hamulak@upol.cz

\begin{abstract}
VALUCH, Jozef; HAMULÁK, Ondrej. Use of Force in Cyberspace. International and Comparative Law Review, 2020, vol. 20, no. 2, pp. 174-191. DOI: 10.2478/ iclr-2020-0023
\end{abstract}

\begin{abstract}
Summary: The ban on the use of force in current international law is of mandatory character. The only exceptions are actions under the auspices of the UN Security Council and self-defence. The article addresses the issue of the use of force, with particular emphasis on cyberspace. As the nature of the conflicts has changed in recent years as well as the space where the individual operations have been moving, a number of fundamental questions arise in this context, which the authors will try to answer.
\end{abstract}

Keywords: use of force, cyberspace, international law, self-defence

\section{Introduction}

Not only the ban on the use of force, but also the threat of force is already firmly enshrined in current international law, while this ban is mandatory. The provisions of Art. 2 (4) of the UN Charter states that "all Members shall refrain in their international relations from the threat or use of force against the territorial integrity or political independence of any state, or in any other manner inconsistent with the Purposes of the United Nations. ${ }^{3}$ This provision expresses one of the fun-

1 doc. JUDr. Jozef Valuch, Ph.D., Faculty of Law, Comenius University in Bratislava, Slovak Republic. He participated in the work on this paper on behalf of the project VEGA no. 1/0579/20 "Armed Conflicts and Cyber Threats - Challenges for International Law in the 21st Century."

2 JUDr. Ondrej Hamulák, Ph.D., Senior Lecturer at the Faculty of Law, Palacký University Olomouc (Czech Republic) and Adjunct Professor in EU Strategic Legal Affairs, TelTech Law School (Estonia). He participated in the work on this paper on behalf of Jean Monnet Network Project 611293-EPP-1-2019-1-CZ-EPPJMO-NETWORK "European Union and the Challenges of Modern Society".

3 UN General Assembly Resolution no. 2526/XXV; Although this is a form of declaration which does not normally involve the legally binding effect, in this case, it is a codification 
damental principles of international law, enshrined, inter alia, in the Declaration on Principles of International Law concerning Friendly Relations and Co-operation among States, adopted by the United Nations General Assembly in 1970.

Several relevant contexts follow from this definition, e.g. that the prohibition applies to the "international relations" of states. This is mainly related to the fact that in the past there were opinions that the issues of colonialism and national liberation struggles belong to the internal affairs of the state and are conceptually not covered by this principle. Today, this current of thought is outdated, and even in the case of repressive measures against a nation exercising its right to self-determination, it would be a violation of the principle of the prohibition of threat by force or the use of force. ${ }^{4}$ However, we consider the fact that the ban is not only focused on acts aimed at the territorial integrity or political independence of states, but it also applies to any other method incompatible with the objectives of the United Nations. These objectives are defined in Art. 1 of the UN Charter ${ }^{5}$ and it may be inferred from this that the intention was to create a presumption of illegality for any threat or use of force. There are only two generally accepted exceptions to the ban on the use of force, namely:

a. actions taken pursuant to the UN Security Council resolution according to Chapter VII of the UN Charter, ${ }^{6}$ including armed actions carried out by regional organizations under the so-called regional agreements with the authorization or consent of the UN Security Council; ${ }^{7}$

b. performance of individual and collective self-defence. ${ }^{8}$

of a general law of a customary nature. Therefore, as it reflects the customary principles in force, its content shall be considered binding. For more details see: VRŠANSKÝ, Peter, VALUCH, Jozef et al.: Medzinárodné právo verejné. Všeobecná čast', Bratislava: Eurokódex, 2012, p. 142.

4 AZUD, Ján. K niektorým otázkam výkladu zásady zákazu hrozby a použitia sily v medzinárodných vztahoch. In: Ročenka medzinárodného práva. Bratislava: Slovenská spoločnost’ pre medzinárodné právo pri SAV, 2008, p. 10.

5 The UN objectives defined in Art. 1 of the UN Charter include: "1) To maintain international peace and security, and to that end: to take effective collective measures for the prevention and removal of threats to the peace, and for the suppression of acts of aggression or other breaches of the peace, and to bring about by peaceful means, and in conformity with the principles of justice and international law, adjustment or settlement of international disputes or situations which might lead to a breach of the peace; 2) To develop friendly relations among nations based on respect for the principle of equal rights and self-determination of peoples, and to take other appropriate measures to strengthen universal peace; 3) To achieve international co-operation in solving international problems of an economic, social, cultural, or humanitarian character, and in promoting and encouraging respect for human rights and for fundamental freedoms for all without distinction as to race, sex, language, or religion; and 4) To be a centre for harmonizing the actions of nations in the attainment of these common ends."

6 For more details see: Art. 41 and 42 of the UN Charter.

7 For more details see: Art. 53 of the UN Charter.

8 For more details see: Art. 51 of the UN Charter; porovnaj: SÝKOROVÁ, Michaela: Jus cogens v medzinárodnom práve, Praha: Univerzita Karlova, 2019, p. 102; alebo BEDNÁR, Daniel: Medzinárodné právo ozbrojeného konfliktu a 21. Storočie. In: Mílniky práva v stre- 


\section{Use of force and international law}

Article 2 (4) of the UN Charter was revolutionary in its extension to threats. Of course, only those threats of the use of force that would otherwise be qualified as illegal. ${ }^{9}$ However, the United Nations Charter itself does not provide any criteria for determining when an act constitutes the use of force. Therefore, experts often rely on the case of Nicaragua when discussing the appropriate threshold for the use of force. ${ }^{10}$ It is in this case that the International Court of Justice has stated, inter alia, that in determining whether specific acts constitute an "armed attack", their "scope and effects" shall be taken into account. It is intended to express quantitative and qualitative factors, which are to be analysed while determining whether a cyber operation constitutes the use of force. The group of experts working on Tallinn Manual 2.0 also agreed that there is no reason to exclude cyber operations from the scope of actions that may constitute the use of force if their scope and effects are comparable to the scope and effects of noncyber operations that could be qualified.

There is no authoritative definition or criteria in current international law for determining what constitutes a "threat" or "use of force". Some categories of coercive measures do not constitute the use of force. As soon as at a conference in San Francisco in 1945, states considered and subsequently rejected a proposal to include economic measures among the forms of use of force. ${ }^{11}$ It was a conference that ended on 26th June 1945 with the adoption of the UN Charter. ${ }^{12}$ This issue reappeared a quarter of a century later, during the process leading to the adoption of the above-mentioned Declaration of Principles. The answer to the question of whether "force" encompasses all forms of coercion, including which that are of political or economic nature and result in endangering the territorial

doeurópskom priestore 2019. Bratislava: Právnická fakulta UK, 2019, pp. 57-61.

9 SCHMITT, Michael, N. Cyber Operations in International Law: The Use of Force, Collective Security, Self-Defene, and Armed Conflict. In Proceedings of a Workshop on Deterring Cyberattacks: Informing Strategies and Developing Options for U.S. Policy. Washington: The National Academies Press, 2010, p. 153.

10 Nicaragua judgment: This was the judgment of the International Court of Justice of $27^{\text {th }}$ June 1986. In 1979, a coup took place in Nicaragua. The political situation resulted in a civil war between the new Sandinista government and the so-called contras that were supported by the USA. In 1984, the Sandinista government of Nicaragua turned to the International Court of Justice because it considered the behavior of the USA a violation of international law. The court stated, among others, that the USA had been trying to overthrow the government of Nicaragua by supporting, training and funding the contras and thus interfering in internal affairs, that some of the attacks of the USA violated the prohibition on the use of force as well as the state's territorial sovereignty. At the same time, it stated that the so-called contras are not attributable to the United States. For more details see: BUCHTA, Tomáš; SÝKOROVÁ, Michaela. Najdôležitejšie rozsudky v medzinárodnom práve verejnom, Bratislava: C. H. Beck, 2016, pp. 48-52.

11 Tallinn Manual 2.0, pp. 330-331.

12 VALUCH, Jozef; RIŠOVÁ, Michaela; SEMAN, Radoslav. Právo medzinárodných organizácií, Praha: C. H. Beck, 2011, p. 92. 
integrity or political independence of another state was negative. Therefore, e.g. non-destructive cybernetic psychological operations designed solely to undermine trust in the government, or a state ban on e-commerce with another state aimed at causing negative economic consequences are not qualified as the use of force.

Another argument of this kind may be that the International Court of Justice has also stated in the case of Nicaragua that only the financing of guerrillas (partisan units) involved in operations against another state does not reach the threshold of the use of force. From this, it may be deduced that e.g. merely funding a group of hackers carrying out cyber operations as part of an insurgency would not be the use of force against a state involved in an armed conflict with insurgents. ${ }^{13}$

At the same time, however, it should be added here that the International Court of Justice ruled in this case that the armament and training of guerrillas (partisan groups) involved in hostile activities against another state constituted a prohibited use of force even if they had not reached the level of armed attack. ${ }^{14}$ It follows from this that the use of force needs not involve the employment of military or other armed forces by the state concerned. Therefore, e.g. a state that provides an organized armed group with a malware and training necessary to conduct cyber operations against another state participates in the use of force against another state for as long as such supply and training allow the group to conduct cyber operations involving the use of force. ${ }^{15}$

In relation to the wording "threat or use of force", it is also worth mentioning here that neither the UN Charter nor the above-mentioned Declaration of Principles limits this ban to "armed force" only but perceives it in a broader context. This ban may thus include unarmed, non-military physical force, such as drainage of water from the dam. ${ }^{16}$ It may be any threat or use of force that is directed against the territorial integrity or political independence of a state or is otherwise incompatible with the UN objectives. A threat may then be understood as a direct or indirect act of a state which raises legitimate concerns about another state's political independence or territorial integrity. It does not necessarily have to be addressed to a specific state, it may also be directed towards the entire international community. ${ }^{17}$ In practice, these may be the situations

13 Tallinn Manual 2.0, p. 331.

14 Nicaragua judgment, paragraph 228. According to the International Court of Justice, the difference between a threat or use of force (including armed forces) and an armed attack is based on the "scope and effects of the operation". Nicaragua judgment, paragraph 195.

15 Tallinn Manual 2.0, p. 332.

16 For more details see: FOLTZ, Andrew, C. Stuxnet, Schmitt Analysis, and the Cyber "Use-of-Force" Debate. Joint Force Quarterly, 2012, issue 64, p. 42.

17 However, not every threat automatically means a threat to peace under Article 39 of the UN Charter. Its assessment rests with the UN Security Council, which may subsequently decide on enforcement measures under Art. 41 and 42 of the UN Charter. If it is not a 
where a state threatens by the use force, occupation of a territory, naval blockade, carries out military mobilization or unusually increases military forces near the border, etc. ${ }^{18}$

On the basis of the facts mentioned above, it may be concluded that a cyber operation which poses a threat or the use of force against the territorial integrity or political independence of a state, or which is otherwise incompatible with the objectives of the United Nations, is also contrary to the principle in concern. ${ }^{19}$ Even the International Court of Justice has stated that Art. 2 (4) and Art. 51 of the UN Charter regarding the prohibition of the use of force and self-defence applies to any use of force, regardless of the weapons used. ${ }^{20}$ The International Expert Group also agreed that this was a reflection of customary international law. ${ }^{21}$ Article 2 (4) of the UN Charter, as well as the related customary law, thus set a threshold for violation of international law.22

It is also important to realize that actions described as "use of force" do not always have to be carried out by armed forces of a state. For example, it is clear that a cyber operation involving the use of force if carried out by the armed forces would also be a use of force as well as if carried out by state intelligence agencies or a private entity whose conduct is imputable to the state.

Although Art. 2 (4) of the UN Charter applies exclusively to members of the United Nations, this ban also applies to non-member states on the basis of customary international law. However, Article 2 (4) of the UN Charter and customary international law do not apply to the actions of non-state actors, including individuals, organized groups and terrorist organizations, unless they are imputable to the state. These actions of non-state actors may be illegal according to international and national law, but not as a violation of the ban on the use of force.

On the other hand, the fact that a cyber operation does not reach the level of use of force does not mean that it is legal under international law. It may constitute a breach of the sovereignty of the state or a breach of the prohibition on interfering in the internal affairs of the state. ${ }^{23}$

threat to peace, a breach of peace or an act of aggression, a procedure under Chapter VI (peaceful settlement of disputes) may also be stipulated.

18 VRŠANSKÝ, Peter, VALUCH, Jozef et al.: Medzinárodné právo verejné. Všeobecná čast. Bratislava: Eurokódex, 2012, pp. 144-145.

19 Tallinn Manual 2.0, rule no. 68, p. 329.

20 Nuclear Weapons Advisory opinion, par. 39.

21 Tallinn Manual 2.0, p. 328.

22 SCHMITT, Michael, N. Cyber Operations in International Law: The Use of Force, Collective Security, Self-Defene, and Armed Conflict. In Proceedings of a Workshop on Deterring Cyberattacks: Informing Strategies and Developing Options for U.S. Policy. Washington: The National Academies Press, 2010, p. 154; See also FERNICOLA, Gia. Once Upon a Time in Cyberspace: A Grim Reality about the Dangers of Cyberwarfare. International and Comparative Law Review, 2020, vol. 20, no. 2, pp. 77-96. DOI: 10.2478/iclr-2020-0004.

23 Tallinn Manual 2.0, p. 330. 
As a result of the facts mentioned above, the threshold for the use of force has traditionally been considered to lie somewhere between purely economic and political pressure on the one hand and activities that cause physical harm or injury on the other. It is the determination of the threshold for the use of force that has proved to be extremely difficult in connection with cyber operations. ${ }^{24}$

When looking closer at the terms "use of force" and "armed attack", we gradually find out that the latter represents a threshold at which a state may legally use force under the right to self-defence. In the case of Nicaragua, the International Court of Justice has distinguished the most serious forms of "use of force" (such as those which constitute an "armed attack" in the sense of the right to self-defence) from other less serious forms. It may be inferred from this, that a cyber operation which reaches the level of "armed attack" in terms of scale and effects and which is carried out or otherwise imputable to the state is qualified as the "use of force".25

According to a strict resource-based interpretation, even strong disruptive cyber operations in peacetime cannot be considered the use of force because of the lack of traditional kinetic characteristics associated with armed force. However, most experts reject this strict interpretation with respect to the potentially widespread destabilizing consequences of cyber operations. With regard to Art. 2 (4) of the UN Charter and the above-mentioned facts, several experts concluded that a new treaty law related to cyber operations would be appropriate. ${ }^{26}$ Others argue that in the foreseeable future, states will have no real interest in establishing meaningful treaty rules in this area. According to them, the reason is different strategic interests and significant problems related to attributing this type of conduct. They propose existing international standards, albeit imperfect, as appropriate to extrapolate the general principles governing the use of force in cyberspace and call for the gradual extension of international standards within the framework of Art. 2 (4) of the UN Charter. ${ }^{27}$ Over the last two decades, proponents of this step-by-step approach have developed several analytical frameworks to characterize the legality of cyber operations:

- the first one is an approach based on "effects". According this approach, it depends primarily on the quantity of damage caused and not on the means of attack used. The advantage of this approach (which is generally supported by US policymakers and military operators) is that it is relatively easy to apply and acknowledges that states are primarily con-

24 For more details see: WAXMAN, Matthew, C. Cyber-Attacks and the Use of Force: Back to the Future of Article 2 (4). The Yale Journal of International Law, 2011, vol. 36, pp. 445-447. Cited according to: FOLTZ, Andrew, C. Stuxnet, Schmitt Analysis, and the Cyber "Use-of-Force" Debate. Joint Force Quarterly, 2012, issue 64, p. 42.

25 Tallinn Manual 2.0, p. 332.

26 HOLLIS, Duncan B. Why States Need an International Law for Information Operations. Lewis \& Clark Law Review, 2007, vol. 11, no. 4, p. 1053.

27 For more details see: FOLTZ, Andrew, C. Stuxnet, Schmitt Analysis, and the Cyber "Use-of-Force" Debate. Joint Force Quarterly, 2012, issue 64, p. 42. 
cerned about the consequences. The shortcoming is that it deviates from the resource-based approach of the UN Charter and it is based on subjective assessment by states with different strategic capabilities, vulnerabilities and interests;

- the second approach relies on kinetic equivalence, arguing that cyber operations involve the use of force only if the damage caused could previously only be achieved by a kinetic attack. ${ }^{28}$ This generally follows the resource-based approach of the UN Charter, however, it seeks to characterize hostile cyber operations in the so-called grey areas that do not lead to physical damage;

- the third approach applies strict responsibility for any cyber operations targeted on the critical infrastructure of a state and its vital interests due to the serious consequences that could result from such attacks. According to this model, even easy penetration into such systems as e.g. production of electricity, stock exchange, or air traffic control, may provide evidence of hostile intent and thus activate the right to self-defence ${ }^{29}$ enshrined in the UN Charter. This approach "suffers" from the natural subjectivity of defining what constitutes a "critical infrastructure and vital interests" of a country;

- the approach of prof. M. Schmitt, ${ }^{30}$ to which we pay special attention in the following text and which is also known as the so-called Schmitt analysis, is the fourth framework.

\section{Schmitt analysis}

Professor M. Schmitt lists several factors that would influence the assessment of states as to whether or not specific cyber operations involve the use of force. They are based on the recognition that, while states generally want to maintain their freedom of action (motivation to keep the threshold high), they also want to avoid the harmful consequences caused by the actions of others (motivation to keep the threshold low). States will thus seek to balance these conflicting objectives by taking into account the factors set out below. ${ }^{31}$ Professor Schmitt acknowledged that distinguishing the use-of-force threshold is, in fact, about

28 HOLLIS, Duncan B. Why States Need an International Law for Information Operations. Lewis \& Clark Law Review, 2007, vol. 11, no. 4, p. 1041, or GRAHAM, David E.. Cyber Threats and the Law of War. Journal of National Security Law \& Policy, 2010, vol. 4, no. 1, pp. 91-92.

29 HOLLIS, Duncan B. Why States Need an International Law for Information Operations. Lewis \& Clark Law Review, 2007, vol. 11, no. 4, p. 1041.

30 FOLTZ, Andrew, C. Stuxnet, Schmitt Analysis, and the Cyber "Use-of-Force" Debate. Joint Force Quarterly, 2012, issue 64, p. 42.

31 SCHMITT, Michael, N. Cyber Operations in International Law: The Use of Force, Collective Security, Self-Defene, and Armed Conflict. In Proceedings of a Workshop on Deterring Cyberattacks: Informing Strategies and Developing Options for U.S. Policy. Washington: The National Academies Press, 2010, p. 155. 
predicting how states will characterize and respond to cyber incidents in the light of prevailing international standards. In order to assist in such anticipation, its framework bridges resource - and consequence-based approaches. In accordance with the resource-based standard within the meaning of Art. 2 (4) of the UN Charter, its model consists of seven factors, which represent the main differences between permissible (economic and political) and impermissible (armed) instruments of coercion. Applying these factors, the closer the attributes of a cyber operation are to the attributes of the armed force, the more likely states are to characterize the operation as a prohibited use of force. ${ }^{32}$ It should also be borne in mind that these are only the factors influencing states that assess the use of force, not formal legal criteria. ${ }^{33}$ The factors are as follows:

- Severity: Armed attacks threaten physical harm or destruction of property to a greater extent than other forms of coercion. Good physical condition usually tops the hierarchy of human needs. ${ }^{34}$ In this context, the level, extent and duration of the consequences will have a major impact on the assessment of the seriousness of cyber operations. Severity is the most important factor in the analysis. ${ }^{35}$ From the above-mentioned facts it follows that cyber operations which may result in physical harm are closer to an armed attack;

- Immediacy: the negative consequences of armed coercion or its threat usually manifest very quickly, while they manifest more slowly in other forms. The possibility for the state of destination or the international community to seek a peace settlement is thus limited in this case. Therefore, actions with rapid negative consequences without sufficient time to mitigate the harmful consequences are more likely to viewed as the use of force;

- Directness: the consequences of armed coercion are directly linked to actus reus, not as in the case of other forms of coercion, which often depend on other factors as well. Therefore, the prohibition on force eliminates negative consequences with greater certainty. ${ }^{36}$ The more direct

32 FOLTZ, Andrew, C. Stuxnet, Schmitt Analysis, and the Cyber "Use-of-Force" Debate. Joint Force Quarterly, 2012, issue 64, pp. 42-43.

33 Tallinn Manual 2.0, p. 333.

34 SCHMITT, Michael, N. Computer Network Attack and the Use of Force in International Law: Thoughts on a Normative Framework (1999). Columbia Journal of Transnational Law, Vol. 37, 1998-99, p. 914.

35 SCHMITT, Michael, N. Cyber Operations in International Law: The Use of Force, Collective Security, Self-Defene, and Armed Conflict. In Proceedings of a Workshop on Deterring Cyberattacks: Informing Strategies and Developing Options for U.S. Policy. Washington: The National Academies Press, 2010, pp. 155-156

36 SCHMITT, Michael, N. Computer Network Attack and the Use of Force in International Law: Thoughts on a Normative Framework (1999). Columbia Journal of Transnational Law, Vol. 37, 1998-99, p. 914. 
the causal link between the cyber operation and the consequences is, the more likely states are to consider it the use of force;

- Invasiveness: the more a computer operation undermines the territorial integrity or sovereignty of a state, the more likely it is to be considered the use of force.$^{37}$ Indeed, in the case of armed coercion, it may be stated that the act which causes the damage usually passes to the country of destination, whereas in the case of economic measures, the activities generally occur outside the borders of the state of destination. As a result, although armed and economic acts may have roughly similar consequences, the former constitute greater interference with the rights of the state of destination and are therefore more likely to undermine international stability;

- Measurability: while the consequences of an armed operation are usually easily identifiable (e.g. a certain level of destruction), the real negative consequences of other forms of coercion are more difficult to measure. ${ }^{38}$ States are therefore more likely to consider a cyber operation a use of force view a cyber operation as a use of force if the consequences are easily identifiable and objectively quantifiable;

- Presumptive Legitimacy: To the extent certain activities are legitimate outside of the cyber context, they remain so in the cyber domain, for example, espionage, psychological operations and propaganda. ${ }^{39}$ In most cases, whether under national or international law, the use of violence is considered illegitimate unless there is a specific exception, such as selfdefence. In contrast, most other forms of coercion, again in the national or international sphere, are likely to be legal unless there exists a ban related to them. The consequences of armed coercion are therefore probably inadmissible, while the consequences of other coercive acts are not (as a very generalized rule); ${ }^{40}$

- Responsibility: Articles on the responsibility of the state regulate the situations in which the state will be responsible for a cyber operation. The closer the nexus between the cyber operation and a state, the more likely it will be characterized as a use of force and as a higher risk to the international stability. ${ }^{41}$

37 FOLTZ, Andrew, C. Stuxnet, Schmitt Analysis, and the Cyber "Use-of-Force" Debate. Joint Force Quarterly, 2012, issue 64, p. 43.

38 SCHMITT, Michael, N. Computer Network Attack and the Use of Force in International Law: Thoughts on a Normative Framework (1999). Columbia Journal of Transnational Law, Vol. 37, 1998-99, pp. 914-915.

39 FOLTZ, Andrew, C. Stuxnet, Schmitt Analysis, and the Cyber "Use-of-Force" Debate. Joint Force Quarterly, 2012, issue 64, p. 43.

40 SCHMITT, Michael, N. Computer Network Attack and the Use of Force in International Law: Thoughts on a Normative Framework (1999). Columbia Journal of Transnational Law, Vol. 37, 1998-99, p. 915.

41 SCHMITT, Michael, N. Cyber Operations in International Law: The Use of Force, Collective Security, Self-Defene, and Armed Conflict. In Proceedings of a Workshop on Deterring 
However, Professor Schmitt himself acknowledged that evaluation according to the above factors also bears signs of inaccuracy and subjectivity. These factors are useful but not decisive and should not be used mechanically. They should be applied according to the relevant context and their meaning may vary from case to case. He himself claims that this is not a complete calculation of factors, although it is often perceived like that. In general, it may be stated that this socalled Schmitt analysis has stood the test of time and remains one of the most commonly cited frameworks for characterizing the use of force in cyberspace. ${ }^{42}$ It also became the basis for the elaboration of the relevant provisions in the Tallinn Manual 2.0, which elaborated and supplemented them into the following form:

- Severity: even in this case it will be the most important factor of the analysis. Consequences involving physical harm to individuals or property will themselves qualify a cyber operation as the use of force. This does not apply to those who create only minor discomfort or irritation. The more the consequences interfere with critical national interests, the more they contribute to the view of a cyber operation as the use of force. In particular, scope, duration, and intensity of the consequences will have a major impact on the assessment of their severity. ${ }^{43}$ Questions capable of approaching the degree of severity: What is the damage caused by a cyber operation like? In what large territorial areas of the given state has this damage occurred?

- Immediacy: the sooner the consequences of the operation become apparent, the less chance there is for states to seek peaceful accommodation of the dispute and to mitigate its harmful effects. It is clear that states are more concerned about the immediate consequences than those that are delayed or appear slowly and continuously. They are more likely to then characterize a cyber operation that produces immediate results as the use of force than the one for which it takes weeks or months to achieve the intended effects. ${ }^{44}$ Questions capable of approaching the degree of immediacy: How quickly did the negative consequences of the cyber operation occur? Did the consequences of the cyber operation manifest immediately or after a long time, and how quickly did they disappear?

- Directness: prof. M. Schmitt ${ }^{45}$ states in his work that the greater the downturn between the initial act and its consequences, the less states

Cyberattacks: Informing Strategies and Developing Options for U.S. Policy. Washington: The National Academies Press, 2010, p. 156.

42 FOLTZ, Andrew, C. Stuxnet, Schmitt Analysis, and the Cyber "Use-of-Force" Debate. Joint Force Quarterly, 2012, issue 64, p. 43.

43 Tallinn Manual 2.0, p. 334.

44 Tallinn Manual 2.0, p. 334.

45 SCHMITT, Michael, N. Computer Network Attack and the Use of Force in International Law: Thoughts on a Normative Framework (1999). Columbia Journal of Transnational Law, Vol. 37, 1998-99, p. 914. 
will regard the actor as a violator of the ban on the use of force. While the previous criterion of immediacy focuses on the temporal aspect of the consequences in question, directness examines the causal link. The causal link between the initial activities and their effects is often indirect - e.g. economic sanctions may take weeks or even months to have a significant impact. On the other hand, in the case of armed activities, the causes and consequences are closely linked. An explosion that directly damages people or objects is an example of this. Therefore, cyber operations where the cause and effect are clearly linked are more likely to be viewed as the use of force than those where this is not the case. ${ }^{46}$ Questions capable of approaching the degree of directness: Were the negative consequences caused by the cyber operation? Would a tragedy occur even without a previous cyber operation?

- Invasiveness: this criterion concerns the extent to which cyber operations affect the state of destination or its computer systems contrary to the interests of that state. Generally, the more secure the computer system of destination is, the greater is the concern about the intrusion of such system. For example, intrusion into a secure military system is more invasive than just exploiting the vulnerability of an openly accessible system in a civilian university. The domain name is also a very visible indicator in cyberspace and for this reason, it may be important in assessing the perception of the invasiveness of the operation. For this reason, cyber operations that specifically focus on the domain name of a particular state or government body (e.g., "gov.sk") may be considered more invasive than non-state specific domain operations. (e.g. ".com"). For example, a cyber espionage is highly invasive. However, this in itself does not reach the level of use of force. In addition, there is no direct ban on espionage in international law. ${ }^{47}$ Questions capable of approaching the degree of invasiveness: What was the security level of the system which was attacked? What type of systems, respectively, servers have been affected by the cyber operations?

- Measurability of effects: represents a factor which is also based on the work of professor M. Schmitt. ${ }^{48}$ It results from a greater willingness of states to characterize actions as the use of force when the consequences are obvious. While the armed forces carried out operations that qualified as the use of force and the effects of these operations were generally measurable (as in the case of post-battle damage assessment), the consequences may be less obvious in the cybernetic area. Therefore, the more

46 Tallinn Manual 2.0, p. 334.

47 Tallinn Manual 2.0, pp. 334-335.

48 SCHMITT, Michael, N. Cyber Operations in International Law: The Use of Force, Collective Security, Self-Defene, and Armed Conflict. In Proceedings of a Workshop on Deterring Cyberattacks: Informing Strategies and Developing Options for U.S. Policy. Washington: The National Academies Press, 2010, p. 156. 
quantifiable and identifiable the set of consequences, the easier it will be for the state to assess whether a given cyber operation has reached a level of a use of force. Therefore, a cyber operation that can be specifically assessed (e.g. amount of data corrupted, percentage of servers blocked) is more likely to be considered the use of force than an operation with consequences that are difficult to measure. ${ }^{49}$ Questions capable of approaching the degree of measurability of effects: How and if the consequences of a cyber operation can be quantified at all? What is the total number of negative consequences of a cyber operation?

- Military character: the mere link between a cyber operation and military operation increases the likelihood of its characterization as the use of force. This statement is also supported by the fact that the UN Charter pays due attention to military actions. As soon as in the preamble, it is stated that the armed forces will be used only in the common interest. ${ }^{50}$ Article 44 of the UN Charter, in turn, uses the term "force" without the qualification "armed" in a situation which clearly refers to the use of military force. ${ }^{51}$ In addition to this, the use of force has traditionally been understood as the force using military or other armed forces. States themselves may then take into account the military nature of the cyber infrastructure against which the cyber operation is directed..$^{52}$ Questions capable of approaching the degree of military character: Is there a nexus between cyber operations and ongoing military operations? Were the cyber operations targeted on the military infrastructure of the given state?

- State involvement: The extent of the state involvement in a cyber operation may range from operations carried out by the state itself (e.g. the activities of its armed forces or intelligence services) to those in which its involvement is marginal. The clearer and closer the link between the state and cyber operations, the more likely it is that other states will characterize them as the use of force by that state. ${ }^{53}$ Questions capable of approaching the degree of state involvement: Have the cyber operations been carried out by forces of another state? What is the degree of involvement of another state in the ongoing cyber operations?

49 Tallinn Manual 2.0, pp. 335-336.

50 Preamble to the UN Charter: "...acceptance of principles and institution of methods ensuring that the armed forces are used only in the common interest ... ".

51 Article 44 of the UN Charter: "When the Security Council has decided to use force it shall, before calling upon a Member not represented on it to provide armed forces in fulfilment of the obligations assumed under Article 43, invite that Member, if the Member so desires, to participate in the decisions of the Security Council concerning the employment of contingents of that Member's armed forces."

52 Tallinn Manual 2.0, p. 336.

53 Tallinn Manual 2.0, p. 336. 
- Presumptive legality: In his work, prof. M. Schmitt ${ }^{54}$ states that the essence of international law lies, inter alia, in the fact that acts which are not prohibited are permitted. ${ }^{55}$ This means that unless there is an explicit prohibition enshrined in the treaty or in the form of customary law, the activity is likely to be legal. International law, for example, does not prohibit propaganda, psychological operations, espionage or economic coercion itself. Therefore, acts like these and other such categories entail the presumption of legality. In these circumstances, states are less likely to consider them the use of force. ${ }^{56}$ Questions capable of approaching the presumption of legality: Does a ban enshrined in international law apply to ongoing operations, respectively, activities in general? Are the means used qualitatively similar to others that are considered legitimate under international law? ${ }^{57}$

As prof. M. Schmitt, ${ }^{58}$ claims, the group of experts working on Tallinn Manual 2.0 also agreed that the calculation of the above criteria is not final. Depending on the circumstances, states may reach for other means, such as the prevailing political environment, whether the cyber operation determines the future use of military force, the identity of the attacker, the nature of the target (e.g. critical infrastructure), etc. In addition, these factors need to be applied together. For example, highly invasive operations that cause only inconvenience (e.g. DoS operations - temporary denial of provision of services) are unlikely to be classified as the use of force. On the other hand, some may categorize massive cyber operations that cripple the economy, as the use of force, even though economic pressure is characterized by the presumption of legality. ${ }^{59}$

\section{Self-defence}

The institute of self-defence, in its current positive legal significance within the framework of international law, has stabilized only relatively recently, as it is inherently linked to the establishment of the mandatory ban on the use of force.

54 SCHMITT, Michael, N. Computer Network Attack and the Use of Force in International Law: Thoughts on a Normative Framework (1999). Columbia Journal of Transnational Law, Vol. 37, 1998-99, p. 914.

55 For more details, see the Lotus case before the Permanent Court of International Justice: Lotus judgment.

56 Tallinn Manual 2.0, p. 336; On issues related to international law, see also: VRŠANSKÝ, Peter; BEDNÁR, Daniel. Cyber security and the international law. Bratislava law review. 2017, vol. 1, no. 2, pp. 38-49 or VALUCH, Jozef, GÁBRIŠ, Tomáš, HAMULÁK, Ondrej. Cyber Attacks, Information Attacks and Postmodern Warfare. Baltic Journal of Law and Politics, 2017, vol. 10, no. 1, pp. 63-89.

57 For further questions in the light of which the above criteria may be assessed, see below: Tallinn Manual 2.0, pp. 336-337.

58 FOLTZ, Andrew, C. Stuxnet, Schmitt Analysis, and the Cyber "Use-of-Force" Debate. Joint Force Quarterly, 2012, issue 64, p. 43.

59 Tallinn Manual 2.0, p. 337. 
However, this does not mean that the term "self-defence" is not known from the earlier period. In the times of traditional international law, it was one of the means used to justify the then non-standardized free politics. The ruling of the Tokyo International Military Tribunal of 1948 in re Hirota et autres, which, by the way, stated as obiter dictum that any law - both international and national - which prohibits the use of force also has a restriction of such ban, namely the right to self-defence. ${ }^{60}$

In the current international law, self-defence is the defensive use of force by a state in response to an armed attack by another state. No legal system can deprive its subjects of the right to self-defence. Consequently, the exercise of that right cannot be regarded as international unlawful conduct. ${ }^{61}$ The institute of self-defence therefore serves to stop an armed attack, i.e. to directly enforce the obligation to stop it. If the armed attack can be stopped, the actions representing the performance of self-defence shall be terminated. However, in addition to the temporal aspect, it is important to apply the principle of proportionality. According to this principle, the act of self-defence should be proportionally balanced with respect to the act of attack. However, this does not mean the same intensity or degree, because with regard to the intended goal (stopping the attack), the act of self-defence shall have a slightly higher degree than the attack, but only to a reasonable extent. The principle of effectiveness is therefore limited in this case by the very principle of proportionality. ${ }^{62}$

The institute of self-defence may also be applied in relation to cyber operations. It is true that even a state that is the target of a cyber operation that reaches the level of an armed attack may exercise its right to self-defence. Whether a cyber operation constitutes an armed attack depends on its scale and effects. ${ }^{63}$ This is reflected by the right to self-defence enshrined in Art. 51 of the UN Charter. $^{64}$

60 ČEPELKA, Čestmír; ŠTURMA, Pavel. Mezinárodní právo veřejné. Praha: Eurolex Bohemia, 2003, pp. 642-643.

61 MALENOVSKÝ, Jiří Mezinárodní právo veřejné jeho obecná část a poměr k vnitrostátnímu právu, zvlášte $k$ právu českému, 4. opravené a doplněné vydání, Brno: Doplněk, 2008, p. 286.; or VRŠANSKÝ, Peter, VALUCH, Jozef et al.: Medzinárodné právo verejné. V̌seobecná čast'. Bratislava: Eurokódex, 2012, pp. 311-312.

62 VRŠANSKÝ, Peter, VALUCH, Jozef et al.: Medzinárodné právo verejné. Všeobecná čast. Bratislava: Eurokódex, 2012, p. 312.

63 Tallinn Manual 2.0, rule no. 71, p. 339

64 Article 51 of the UN Charter: "Nothing in the present Charter shall impair the inherent right of individual or collective self-defence if an armed attack occurs against a Member of the United Nations, until the Security Council has taken measures necessary to maintain international peace and security. Measures taken by Members in the exercise of this right of self-defence shall be immediately reported to the Security Council and shall not in any way affect the authority and responsibility of the Security Council under the present Charter to take at any time such action as it deems necessary in order to maintain or restore international peace and security." 
However, the use of force involving cyber operations carried out by the state in the exercise of its right of self-defence shall be inevitable and reasonable. Both of these criteria have been confirmed by the International Court of Justice in the Nicaragua case and later in the Oil Platforms case. ${ }^{65}$ Inevitability requires that the use of force (including cyber operations involving the use of force) be necessary to successfully thwart an impending armed attack or deter an ongoing one. ${ }^{66}$ At the same time, the right to use force in self-defence arises when a cyber armed attack occurs or is imminent. Subsequently, it is subject to the requirement of immediacy. ${ }^{67}$ Measures in self-defence shall be of a defensive nature and continue self-defence actions after the cessation of the attack (to enforce the reparative obligation of the attacker) would already constitute illegal armed countermeasures or armed reprisals, which are, however, inadmissible because of their disproportionate effects. ${ }^{68}$

From the wording of Art. 51 of the UN Charter it follows that self-defence may also be exercised collectively. Collective self-defence against a cyber operation constituting an armed attack may be carried out only upon the request of the victim state and within the scope of this request. The right to collective selfdefence entitles a state or several states to either lead a joint defence against an attack launched against them all or to provide help to another state (states) that is a victim of a cyber armed attack. This right, explicitly stated in the UN Charter, may also be found in customary international law. ${ }^{69}$

The conditions for the exercise of collective self-defence have been defined by the International Court of Justice in the Nicaragua case. ${ }^{70}$ This type of selfdefence shall also meet all the requirements of individual self-defence and, in addition, two other conditions: the victim shall publicly declare that it has been attacked and other states shall request military assistance. ${ }^{71}$ However, collective self-defence shall be distinguished from collective security in accordance with Chapter VII of the UN Charter. The main difference is that while the institute of collective self-defence monitors a decentralized defensive response to an armed attack, the measures under Art. 39-42 of the UN Charter is a centrally organized enforcement action of the international community.

It may be said that self-defence, as an exceptional and temporary measure, fills the time between the attack and the institutionalized coercive response to

65 Nicaragua judgment, par. 176, 194; Oil Platforms judgment: Oil Platforms (Iran v. USA), 2003, ICJ 161 (6 November), Sub-sections 43, 73-74, 76

66 Tallinn Manual 2.0, rule no. 72, p. 348

67 Tallinn Manual 2.0, rule no. 73, p. 350

68 ČEPELKA, Čestmír; ŠTURMA, Pavel. Mezinárodní právo veřejné. Praha: Eurolex Bohemia, 2003, p. 648.

69 Tallinn Manual 2.0, p. 354.

70 Nicaragua judgment.

71 ČEPELKA, Čestmír; ŠTURMA, Pavel. Mezinárodni právo veřejné. Praha: Eurolex Bohemia, 2003, p. 647. 
it carried out through the UN Security Council, provided, of course, that it is operational. $^{72}$

It should also be borne in mind that measures involving cyber operations carried out by states in the exercise of their right to self-defence under the UN Charter shall be notified without delay to the UN Security Council, ${ }^{73}$ as a central link in the global collective security system. ${ }^{74}$

\section{Conclusion}

There is no authoritative definition or criteria in current international law for determining what constitutes a "threat" or "use of force". For example, the decision-making activity of the International Court of Justice (the Nicaragua case, etc.) could help us in connection with the given definition.

Professor M. Schmitt's analysis plays an extremely important role in assessing the issue of the use of force in relation to cyberspace. The so-called Schmitt analysis lists several factors that would influence assessment by the states of whether or not specific cyber operations involve the use of force. Its framework bridges the approaches based on resources and consequences. However, these are factors influencing states that assess the use of force, not formal legal criteria: ${ }^{75}$ severity, immediacy, directness, invasiveness, measurability, presumptive legitimacy and responsibility.

Today, it may be stated that this so-called Schmitt analysis has stood the test of time and remains one of the most commonly cited frameworks for characterizing the use of force in cyberspace. ${ }^{76}$ On the other hand, the fact that a cyber operation does not reach the level of use of force does not mean that it is legal under international law. It may constitute a breach of the sovereignty of the state or a breach of the prohibition of interfering in the internal affairs of the state. ${ }^{77}$

Comparing the content of the terms "use of force" and "armed attack", we also find out that the latter represents a threshold at which a state may legally use force under the right to self-defence. It also follows from the above facts that the institute of self-defence may also be applied in relation to cyber operations. It is true that even a state that is the target of a cyber operation which reaches

72 DAVID, Vladislav; BUREŠ, Pavel; FAIX, Martin; SLADKÝ, Pavel; SVAČEK, Ondřej. Mezinárodní právo veřejné s kazuistikou, 2. aktualizované a přepracované vydání. Praha, Leges, 2011, p. 356.

73 Tallinn Manual 2.0, p. 355.

74 For more details see: VALUCH, Jozef; RIŠOVÁ, Michaela; SEMAN, Radoslav. Právo medzinárodných organizácií, Praha: C. H. Beck, 2011, p. 99 et seq.

75 Tallinn Manual 2.0, p. 333.

76 FOLTZ, Andrew, C. Stuxnet, Schmitt Analysis, and the Cyber "Use-of-Force" Debate. Joint Force Quarterly, 2012, issue 64, p. 43.

77 Tallinn Manual 2.0, p. 330. 
the degree of an armed attack may exercise its right to self-defence. It depends on its extent and effects whether a cyber operation constitutes an armed attack. ${ }^{78}$

\section{List of references}

AZUD, Ján. K niektorým otázkam výkladu zásady zákazu hrozby a použitia sily v medzinárodných vztahoch. In: Ročenka medzinárodného práva. Bratislava: Slovenská spoločnosṫ pre medzinárodné právo pri SAV, 2008.

BEDNÁR, Daniel. Medzinárodné právo ozbrojeného konfliktu a 21. storočie. In: Mílniky práva v stredoeurópskom priestore 2019. Bratislava: Právnická fakulta UK, 2019, pp. $57-61$.

BUCHTA, Tomáš; SÝKOROVÁ, Michaela. Najdôležitejšie rozsudky v medzinárodnom práve verejnom. Bratislava: C. H. Beck, 2016.

ČEPELKA, Čestmír; ŠTURMA, Pavel. Mezinárodní právo veřejné. Praha: Eurolex Bohemia, 2003.

DAVID, Vladislav; BUREŠ, Pavel; FAIX, Martin; SLADKÝ, Pavel; SVAČEK, Ondřej. Mezinárodní právo veřejné s kazuistikou, 2. aktualizované a přepracované vydání. Praha, Leges, 2011.

FERNICOLA, Gia. Once Upon a Time in Cyberspace: A Grim Reality about the Dangers of Cyberwarfare. International and Comparative Law Review, 2020, vol. 20, no. 2, pp. 77-96. DOI: 10.2478/iclr-2020-0004.

Foltz, Andrew, C. Stuxnet, Schmitt Analysis, and the Cyber "Use-of-Force" Debate. Joint Force Quarterly, 2012, issue 64, pp. 40-48.

GRAHAM, David E.. Cyber Threats and the Law of War. Journal of National Security Law \& Policy, 2010, vol. 4, no. 1, pp. 87-102.

Hollis, Duncan B. Why States Need an International Law for Information Operations. Lewis \& Clark Law Review, 2007, vol. 11, no. 4, pp. 1023-1061.

Malenovský, Jiři Mezinárodní právo veřejné jeho obecná část a poměr k vnitrostátnímu právu, zvlášte k právu českému, 4. opravené a doplněné vydání, Brno: Doplněk, 2008.

SCHMITT, Michael, N. Computer Network Attack and the Use of Force in International Law: Thoughts on a Normative Framework. Columbia Journal of Transnational Law, Vol. 37, 1998-99, Available at SSRN: https://ssrn.com/abstract=1603800

SCHMITT, Michael, N. Cyber Operations in International Law: The Use of Force, Collective Security, Self-Defene, and Armed Conflict. In Proceedings of a Workshop on Deterring Cyberattacks: Informing Strategies and Developing Options for U.S. Policy. Washington: The National Academies Press, 2010, pp. 151-178.

SCHMITT, Michael, N. (General ed.): Tallinn Manual 2.0 on the International Law Applicable to Cyber Operations. Cambridge: Cambridge University Press, 2017.

SÝKOROVÁ, Michaela. Jus cogens v medzinárodnom práve. Praha: Univerzita Karlova, Právnická fakulta, 2019.

ŠMIGOVÁ, Katarína. Kybernetické útoky a medzinárodné právo. In: Bratislavské právnické fórum 2013. Bratislava: Univerzita Komenského, Právnická fakulta, 2013, pp. 12241230.

78 Tallinn Manual 2.0, rule no. 71, p. 339; See also: ŠMIGOVÁ, Katarína. Kybernetické útoky a medzinárodné právo. In: Bratislavské právnické fórum 2013. Bratislava: Univerzita Komenského, Právnická fakulta, 2013, pp. 1224-1230. 
VALUCH, Jozef, GÁBRIŠ, Tomáš, HAMULÁK, Ondrej. Cyber Attacks, Information Attacks and Postmodern Warfare. Baltic Journal of Law and Politics, 2017, vol. 10, no. 1, s. 63-89. DOI: 10.1515/bjlp-2017-0003.

VALUCH, Jozef; RIŠOVÁ, Michaela; SEMAN, Radoslav. Právo medzinárodných organizácií. Praha: C. H. Beck, 2011.

VRŠANSKÝ, Peter; BEDNÁR, Daniel. Cyber security and the international law. Bratislava law review. 2017, vol. 1, no. 2, pp. 38-49.

VRŠANSKÝ, Peter; VALUCH, Jozef et al. Medzinárodné právo verejné. Všeobecná čast'. Bratislava: Eurokódex, 2012 .

Waxman, Matthew, C. Cyber-Attacks and the Use of Force: Back to the Future of Article 2 (4). The Yale Journal of International Law, 2011, vol. 36, pp. 421-459.

\section{Documents and judgements:}

The Charter of the United Nations

Lotus judgment - The Case of the SS “Lotus" (France v. Turkey), 1927 PCIJ (ser. A), 1927, No.10 ( $7^{\text {th }}$ September).

Nicaragua judgment - Military and Paramilitary Activities in and against Nicaragua (Nicaragua v. USA) 1986, I. C. J. Reports (27 th June).

Nuclear Weapons Advisory opinion - Legality of the Threat or Use of Nuclear Weapons, Advisory Opinion, 1996, I.C.J. 226 ( $8^{\text {th }}$ July).

Oil Platforms judgment: Oil Platforms (Iran v. USA), 2003, ICJ 161 ( $6^{\text {th }}$ November)

UN General Assembly Resolution. VZ OSN č. 2526/XXV - Declaration on Principles of International Law concerning Friendly Relations and Co-operation among States. 